\title{
Impact of model resolution on chemical ozone formation in Mexico City: application of the WRF-Chem model
}

\author{
X. Tie ${ }^{1,2}$, G. Brasseur ${ }^{1,3}$, and Z. Ying ${ }^{1,4}$ \\ ${ }^{1}$ National Center for Atmospheric Research, Boulder, CO, USA \\ ${ }^{2}$ Institute of Earth Environment, CAS, Chinese Academy of Science, China \\ ${ }^{3}$ Climate Service Center, GKSS, Hamburg, Germany \\ ${ }^{4}$ York University, Department of Earth and Atmospheric Science, York University, Toronto, Canada
}

Received: 1 April 2010 - Published in Atmos. Chem. Phys. Discuss.: 16 April 2010

Revised: 23 August 2010 - Accepted: 9 September 2010 - Published: 28 September 2010

\begin{abstract}
The resolution of regional chemical/dynamical models has important effects on the calculation of the distributions of air pollutants in urban areas. In this study, the sensitivity of air pollutants and photochemical ozone production to different model resolutions is assessed by applying a regional chemical/dynamical model (version 3 of Weather Research and Forecasting Chemical model - WRF-Chemv3) to the case of Mexico City. The model results with 3, 6, 12, and $24 \mathrm{~km}$ resolutions are compared to local surface measurements of $\mathrm{CO}, \mathrm{NO}_{\mathrm{x}}$, and $\mathrm{O}_{3}$. The study shows that the model resolutions of 3 and $6 \mathrm{~km}$ provide reasonable simulations of surface $\mathrm{CO}, \mathrm{NO}_{\mathrm{x}}$, and $\mathrm{O}_{3}$ concentrations and of diurnal variations. The model tends to underestimate the measurements when the resolution is reduced to $12 \mathrm{~km}$ or less. The calculated surface $\mathrm{CO}, \mathrm{NO}_{\mathrm{x}}$, and $\mathrm{O}_{3}$ concentrations at $24 \mathrm{~km}$ resolution are significantly lower than measured values. This study suggests that the ratio of the city size to the threshold resolution is 6 to 1 , and that this ratio can be considered as a test value in other urban areas for model resolution setting. There are three major factors related to the effects of model resolution on the calculations of $\mathrm{O}_{3}$ and $\mathrm{O}_{3}$ precursors, including; (1) the calculated meteorological conditions, (2) the spatial distribution for the emissions of ozone precursors, and (3) the non-linearity in the photochemical ozone production. Model studies suggest that, for the calculations of $\mathrm{O}_{3}$ and $\mathrm{O}_{3}$ precursors, spatial resolutions (resulting from different meteorological condition and transport processes) have larger impacts than the effect of the resolution associated with emission inventories. The model shows that, with coarse resolution of emission inventory $(24 \mathrm{~km})$ and high res-
\end{abstract}

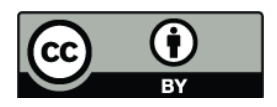

Correspondence to: $\mathrm{X}$. Tie (xxtie@ucar.edu) olution for meteorological conditions $(6 \mathrm{~km})$, the calculated $\mathrm{CO}$ and $\mathrm{O}_{3}$ are considerably improved compared to the results obtained with coarse resolution for both emission inventory and meteorological conditions $(24 \mathrm{~km})$. The resolution of the surface emissions has important effects on the calculated concentration fields, but the effects are smaller than those resulting from the model resolution. This study also suggests that the effect of model resolution on $\mathrm{O}_{3}$ precursors leads to important impacts on the photochemical formation of ozone. This results directly from the non-linear relationship between $\mathrm{O}_{3}$ formation and $\mathrm{O}_{3}$ precursor concentrations. Finally, this study suggests that, considering the balance between model performance and required computation time on current computers, the $6 \mathrm{~km}$ resolution is an optimal resolution for the calculation of ozone and its precursors in urban areas like Mexico City.

\section{Introduction}

In large cities, ozone $\left(\mathrm{O}_{3}\right)$ is often a major air pollutant. For example, in Houston, Texas and the coast cities of California, the ozone concentrations often exceed 200-300 ppbv (Davis and Speckman, 1999; Lei et al., 2004; Zhang et al., 2004; and Mahmud et al., 2008). Such high ozone concentrations have important effects on human health (Noyes et al., 2009). Ozone is photo-chemically produced through a complicated path of photo-chemical processes (Crutzen, 1975; Chameides and Walker, 1976; Sillman, 1995; Kleinman et al., 2000). The formation of tropospheric ozone is nonlinearly related to the presence of carbon monoxide (CO), nitrogen oxide $\left(\mathrm{NO}_{\mathrm{x}}=\mathrm{NO}+\mathrm{NO}_{2}\right)$, and volatile organic compounds (VOCs). In large cities, these ozone precursors are

Published by Copernicus Publications on behalf of the European Geosciences Union. 
mainly emitted from anthropogenic activities, i.e., combustion by automobiles, energy production and industrial activities. Determination of the spatial distribution of the ozone precursor emissions is always a difficult task, especially in urban areas where highly variable sources are present.

In order to better quantify the formation of ozone in large urban areas, numerical chemical/dynamical models are used to assess the path towards high ozone episode events (Lei et al., 2004, 2008; Li et al., 2007; West et al., 2004; Tie et al., 2009a, b; Ying et al., 2009; Zavala et al., 2009a, b; Zhang et al., 2009). However, there are many uncertainties in the calculation of the ozone formation, which are associated with the spatial resolution adopted in three-dimensional chemicaltransport models. The choice of the horizontal resolution adopted in regional chemical/dynamical model has an important impact on the calculated concentrations of ozone and its precursors. Three factors must be considered: (1) the spatial resolution of meteorological features, which affects transport of chemical substances, (2) the spatial resolution of surface emissions, and (3) the spatial resolution at which the non-linear chemical reactions are taking place. These three important issues, which have an impact on the quantitative estimate on the ozone production and distribution rates especially in urban areas, are schematically illustrated in Fig. 1.

Model studies have been performed at varying horizontal resolutions to assess the influence of spatial resolution on several meteorological parameters. For example, Mass et al. (2002) used a regional dynamical model (MM5- the fifthgeneration Pennsylvania State University-National Center for Atmospheric Research Mesoscale Model) to evaluate the effects of model resolution $(4,12$, and $36 \mathrm{~km})$ on calculated wind, temperature, and sea level pressure. They showed that there are significant improvements in the calculation of these dynamical parameters, when increasing the resolution from 36 to $12 \mathrm{~km}$. Colle et al (2000) used the same MM5 model to study precipitation rates at different model resolutions. Their result indicates that calculated precipitation rates are considerably improved by changing the model resolution from 36 to $12 \mathrm{~km}$. Cairns and Corey (1998) also used the MM5 model to analyze mountain winds. Their study suggests that the calculated winds are improved by increasing the model resolution from 27 to $3 \mathrm{~km}$. The impact of model resolution on predicting fire danger was also addressed. Hoadley et al. (2004), for example, used the MM5 model and found little improvement in the prediction of fire danger with increased model resolution. It is likely that significant timing and magnitude errors at all resolutions jeopardize the accurate prediction of fire danger. Misenis and Zhang (2010) suggested that the calculated chemical oxidants are sensitivity to the nesting method at $4 \mathrm{~km}$ than $12 \mathrm{~km}$ resolution.

So far, little attention has been paid to the effects of model resolution on ozone formation. This question involves complicated scientific issues as mentioned in the above paragraphs. The present study focuses on ozone $\left(\mathrm{O}_{3}\right)$ and ozone precursor calculations with various horizontal reso-
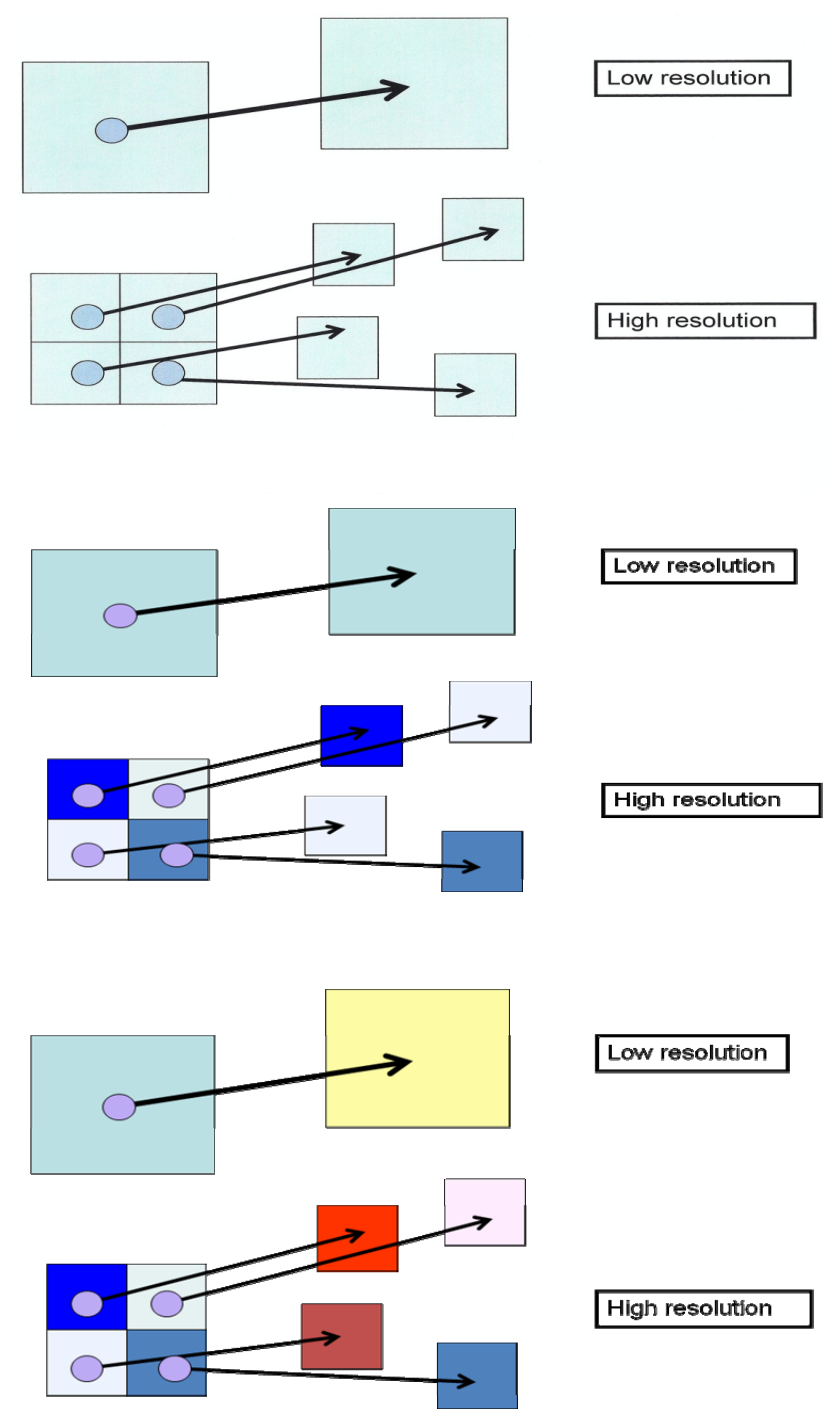

Fig. 1. Schematic representation of the impact of model resolution on the calculation of chemical oxidants in large cities, including (1) impact of resolution on the calculation of meteorological quantities and transport of air pollutants (upper panel); (2) impact of resolution on the calculation of meteorological conditions with changes in emission inventory resolutions (middle panel); (3) impact of resolutions on the calculations of meteorological conditions with changes in both emission inventory resolutions and non-linear photochemistry (lower panel).

lutions. The model used here is a newly developed chemical/dynamical model (version 3 of Weather Research and Forecasting Chemical model - WRF-Chem-v3). It is used to investigate the effects of changing spatial resolution and calculated $\mathrm{O}_{3}$ concentrations in a mega city (Mexico City). The calculated concentrations are compared with surface measurements in the city. This comparison helps in evaluating the effect of resolution on model performance. The paper is organized as follows: In Section 2, we briefly describe the 
regional chemical/dynamical model (WRF-Chem). In Section 3, the simulated concentrations of ozone and ozone precursors are compared to observations. Section 4 focuses on the effect of the model resolution on the calculated ozone distribution and specifically assesses the importance of the resolution at which transport, emission, and photochemical processes are treated.

\section{Chemical model}

The calculations presented in the present study are performed by using the WRF-Chem model (version3). This modeling system includes two components: a dynamical module and a chemical module. The Weather Research and Forecasting (WRF) model used here as the dynamical module is a mesocale numerical weather prediction system designed to serve both for operational forecasting and atmospheric research needs. The effort to develop WRF has been through a partnership between the National Center for Atmospheric Research (NCAR), the National Oceanic and Atmospheric Administration (NOAA), the National Center for Environmental Prediction (NCEP), the Forecast Systems Laboratory (FSL), the Air Force Weather Agency (AFWA), the Naval Research Laboratory, the University of Oklahoma, and the Federal Aviation Administration (FAA). The model equations are solved for fully compressible and nonhydrostatic conditions. The Yonsei University (YSU) PBL scheme (Hong et al., 2006) is used for calculating the PBL height. A detailed description of WRF model can be found on the WRF web-site http://www.wrf-model.org/index.php. In addition to dynamical calculations, a chemical module is coupled on-line with the WRF model. A detailed description of the chemical component of the model is given by Grell et al. (2005). The model is used here with some modifications introduced by Tie et al. (2007).

In this study, the horizontal model resolutions are selected to be $3,6,12$, and $24 \mathrm{~km}$ in a $900 \times 900 \mathrm{~km}$ domain centered around Mexico City. The emission inventory for $\mathrm{SO}_{2}, \mathrm{CO}$, NO, and VOCs are shown in Table 2 of Tie et al. (2009b). In all cases, the total emissions are the same while the horizontal distributions of these emissions vary according to the model resolution that is adapted (illustrated in Fig. 2). The model equations are integrated for several days from 26 to 29 March 2006, and only the last 2 day results (28 and 29 March 2006) are used in the analysis (the first two day results are considered as spin up of the model calculations). Because the model result for the two days is quite similar, the analysis focuses on the result of 28 March. In previous studies, the WRF-Chem model was evaluated by comparing calculated $\mathrm{O}_{3}, \mathrm{CO}$, and $\mathrm{NO}_{\mathrm{x}}$ concentrations to ground measurements from operational monitors in Mexico City (Tie et al., 2007; Ying et al., 2009; Zhang et al., 2009). The simulated concentrations at model resolution of $6 \mathrm{~km}$, the magnitude and timing of simulated diurnal cycles of $\mathrm{O}_{3}, \mathrm{CO}$, and $\mathrm{NO}_{\mathrm{x}}$, and
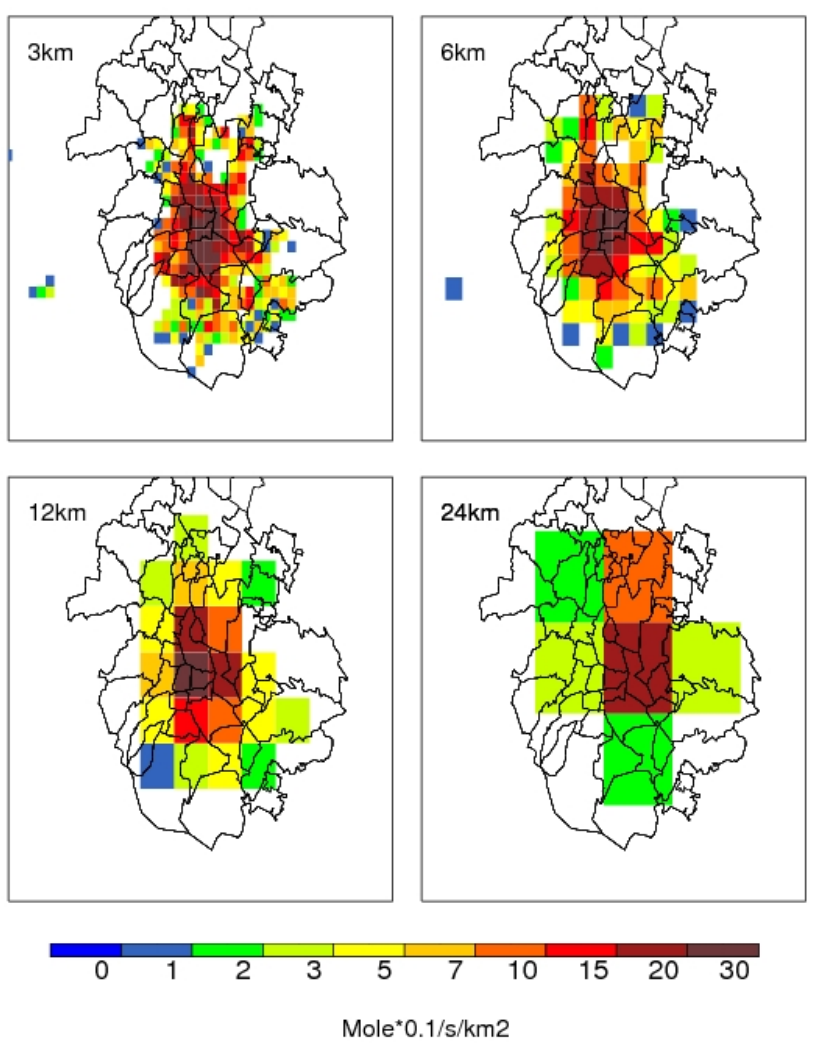

Fig. 2. Emission inventory of carbon monoxide in Mexico City at different resolutions; (a) $3 \times 3 \mathrm{~km}^{2}$, (b) $6 \times 6 \mathrm{~km}^{2}$, (c) $12 \times 12 \mathrm{~km}^{2}$, and (d) $24 \times 24 \mathrm{~km}^{2}$.

the maximum and minimum $\mathrm{O}_{3}$ concentrations were generally consistent with surface measurements. In this study, the difference between calculated and measured values is further evaluated by considering the influence of different model and emission resolutions.

\section{Model results}

In order to evaluate model performance at different resolutions, model results are compared to surface measurements in Mexico City. Air pollutants in Mexico City have been monitored routinely since 1986 by an automatic air quality monitoring network (RAMA) (Molina and Molina, 2002). The locations of the measurement sites are shown in Fig. 3 and detailed in Table 1. As indicated in Table 1, there is a total of 15 measurement sites. For example, the red dots show sites provide $\mathrm{O}_{3}$ measurements only, green dots correspond to sites where $\mathrm{CO}$ and $\mathrm{NO}_{\mathrm{x}}$ concentrations are measured, and blue dots correspond to measurement sites for $\mathrm{O}_{3}, \mathrm{CO}$, and $\mathrm{NO}_{\mathrm{x}}$ concentrations. On 28 March, the observed noon time wind was blowing from the SSW with wind speeds of 5$10 \mathrm{~m} / \mathrm{s}$ and clear sky conditions (Fast 2007). The simulated wind is generally from the south with a speed of $3-8 \mathrm{~m} / \mathrm{s}$ at 
Table 1. The information of surface measurement sites in Mexico City for $\mathrm{O}_{3}, \mathrm{CO}$, and $\mathrm{NO}_{\mathrm{x}}$.

\begin{tabular}{lllll}
\hline Sites & Lon & Lat & Name & Measured Spec. \\
\hline 1 & -99.01 & 19.25 & TAH & $\mathrm{O}_{3}$ \\
2 & -99.18 & 19.26 & TPN & $\mathrm{O}_{3}$ \\
3 & -99.15 & 19.31 & SUR & $\mathrm{CO}, \mathrm{NO}_{\mathrm{x}}$ \\
4 & -99.20 & 19.33 & PED & $\mathrm{O}_{3}, \mathrm{CO}, \mathrm{NO}_{\mathrm{x}}$ \\
5 & -99.12 & 19.34 & TAX & $\mathrm{O}_{3}$ \\
6 & -99.30 & 19.36 & CUA & $\mathrm{O}_{3}$ \\
7 & -99.20 & 19.37 & PLA & $\mathrm{CO}, \mathrm{NO}_{\mathrm{x}}$ \\
8 & -99.08 & 19.42 & $\mathrm{HAN}$ & $\mathrm{O}_{3}, \mathrm{CO}, \mathrm{NO}_{\mathrm{x}}$ \\
9 & -99.14 & 19.44 & LAG & $\mathrm{O}_{3}, \mathrm{CO}, \mathrm{NO}_{\mathrm{x}}$ \\
10 & -99.20 & 19.45 & TAC & $\mathrm{O}_{3}, \mathrm{CO}, \mathrm{NO}_{\mathrm{x}}$ \\
11 & -99.20 & 19.53 & TLA & $\mathrm{CO}, \mathrm{NO}_{\mathrm{x}}$ \\
12 & -99.03 & 19.53 & SAG & $\mathrm{O}_{3}, \mathrm{CO}, \mathrm{NO}_{\mathrm{x}}$ \\
13 & -99.18 & 19.60 & TLI & $\mathrm{CO}, \mathrm{NO}_{\mathrm{x}}$ \\
14 & -99.10 & 19.66 & VIF & $\mathrm{CO}, \mathrm{NO}_{\mathrm{x}}$ \\
15 & -98.90 & 19.47 & CHA & $\mathrm{O}_{3}$ \\
\hline
\end{tabular}

The reds represents for $\mathrm{O}_{3}$ measurement only; the yellows for $\mathrm{CO}$ and $\mathrm{NO}_{\mathrm{x}}$ only; and the blues for $\mathrm{O}_{3}, \mathrm{CO}$, and $\mathrm{NO}_{\mathrm{x}}$.

noontime outside of the city (see Fig. 3). However, inside the city, there is an indication that the mountain breeze had a strong influence on both the wind direction and the wind speed. In Table 1, the measurement sites are listed from south to north, except in the case of the CHA site, which is located at a far-east location. This particular site is generally not substantially affected by city pollution.

In order to better understand the individual contributions to the calculation of air pollutants of different processes (such as meteorological condition, transport process, emissions, and non-linear photochemistry) due to changes in horizontal resolution of the model, several chemical species $\left(\mathrm{CO}, \mathrm{NO}_{\mathrm{x}}\right.$, and $\mathrm{O}_{3}$ ) are calculated at different resolutions and compared to the measured surface concentrations. For example, the calculated $\mathrm{CO}$ concentrations at different resolutions mainly result from the changes in meteorological conditions, transport processes, and emission inventories, but are not substantially affected by non-linear photochemistry ( $\mathrm{CO}$ has a slow destruction reaction rate by $\mathrm{OH}$ ). By contrast, $\mathrm{O}_{3}$ is strongly controlled by non-linear photochemistry. As a result, comparisons of calculated patterns for different chemical species can highlight the contributions of different processes that are affected by model resolution.

\subsection{Carbon monoxide}

Figure 4 shows the calculated surface distribution of carbon monoxide at different horizontal resolutions. It indicates that the surface $\mathrm{CO}$ concentrations are generally characterized by the same horizontal patterns at 3, 6, 12, and $24 \mathrm{~km}$ resolution. The surface $\mathrm{CO}$ concentrations are highest in the center of the city. Carbon monoxide is transported northward as plumes in

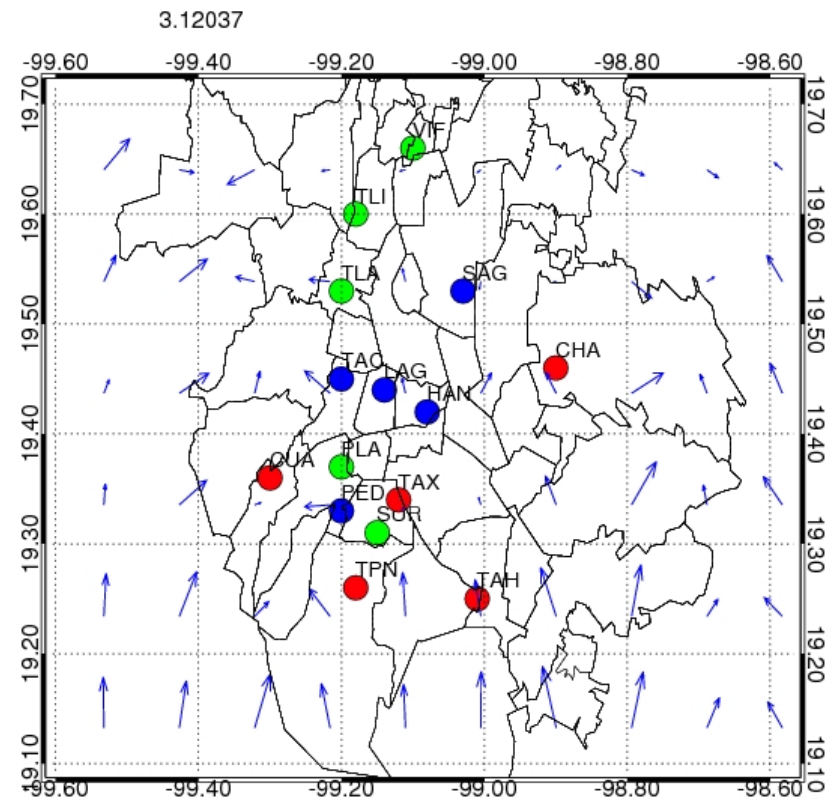

Fig. 3. Surface measurement sites in Mexico City. The red dots represent sites for only ozone measurements; the green dots represent the sites when $\mathrm{CO}$ and $\mathrm{NO}_{\mathrm{x}}$ are measured; and the blue dots represent the sites when $\mathrm{CO}, \mathrm{NO}_{\mathrm{x}}$, and $\mathrm{O}_{3}$ are measured. The calculated wind pattern at 12 p.m. on 28 March 2006 is also shown.

the downwind area. However, there are apparent differences in the detailed horizontal structures. The peak $\mathrm{CO}$ concentrations are higher in high resolution ( 3 and $6 \mathrm{~km})$ models than in lower resolution (12 and $24 \mathrm{~km}$ ) models. For example, the maximum concentrations reach $2000-3000$ ppbv at the center of the city when the 3 and $6 \mathrm{~km}$ resolutions are adopted, but reach only $1000-1500$ ppbv at the center of the city when $12 \mathrm{~km}$ resolution is used. This maximum becomes only $700 \mathrm{ppbv}$ with the $24 \mathrm{~km}$ resolution model. At low resolution, the $\mathrm{CO}$ concentration patterns are therefore considerably more diffused than at higher resolution. In addition, one notices that the high CO concentration area is shifted northward in the $24 \mathrm{~km}$ resolution case due to the coarse resolution adapted for the emissions (see Fig. 2). The lack of detailed spatial structure of high concentrations in the $\mathrm{CO}$ concentration pattern together with a northward shift in the CO distribution has important impacts for air pollution issues, and specially for the calculation of the production of secondary pollutants.

Figure 5a provides a comparison between measured and calculated diurnal variations of surface $\mathrm{CO}$ concentrations. In both cases, two maxima and two minima are seen in both the measurements and the calculations. The first maximum of $\mathrm{CO}$ occurs around $8 \mathrm{AM}$ and second one in late evening. As explained by Tie et al. (2007), this strong diurnal variation is mainly due to the combination of diurnal variations in the height of the planetary boundary layer (PBL) and in the $\mathrm{CO}$ emission rate. The calculated diurnal variations have 

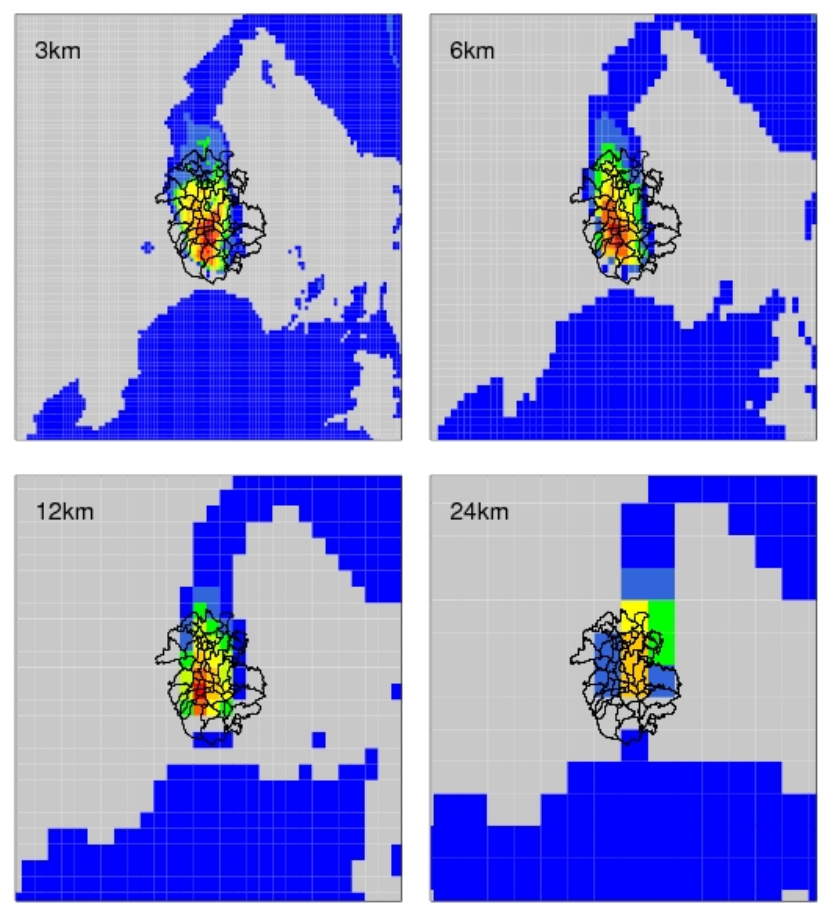

$100 \quad 150200300 \quad 4005007001000150020003000$

Fig. 4. Calculated CO surface mixing ratio (ppbv) at different resolutions in Mexico City, including; (a) $3 \times 3 \mathrm{~km}^{2}$, (b) $6 \times 6 \mathrm{~km}^{2}$, (c) $12 \times 12 \mathrm{~km}^{2}$, and (d) $24 \times 24 \mathrm{~km}^{2}$.

similarities with the measured variations. However, some distinguished differences are noticeable, especially for in the low resolution $(24 \mathrm{~km})$ model configuration. Less noticeable differences are found for 3 and $6 \mathrm{~km}$ resolution. Note, however that, the evening maximum is somewhat different in the 3 and $6 \mathrm{~km}$ resolution models. At $12 \mathrm{~km}$ resolution, the calculated $\mathrm{CO}$ diurnal variation is similar to the variations obtained at 3 and $6 \mathrm{~km}$. However, the magnitude of the morning maximum is less pronounced, and at some sites (SUR, PED, LAG, and HAN), the calculated morning maximum is underestimated. As indicated in Figs. 2 and 3, these sites are located at the center of the city where the emission rate are highest. As a result, the choice of a lower emission resolution $(12 \mathrm{~km})$ causes dilution of the calculated $\mathrm{CO}$ in the vicinity of these sites, leading to an underestimation of the calculated $\mathrm{CO}$ concentrations. However, on the north side of the city (TLA, SAG, TLI, and VIF), the calculated CO concentration at $12 \mathrm{~km}$ resolution is very similar to the calculated $\mathrm{CO}$ at 3 and $6 \mathrm{~km}$ resolution. For a resolution of $24 \mathrm{~km}$, the calculated CO concentrations are substantially different from the corresponding concentrations derived at 3 and $6 \mathrm{~km}$. They largely underestimate the measured values. In the center of the city (SUR, PED, PLA, and LAG), the calculated CO concentrations are close to background values (100 ppbv) and no diurnal variation is apparent, suggesting that this coarse res-
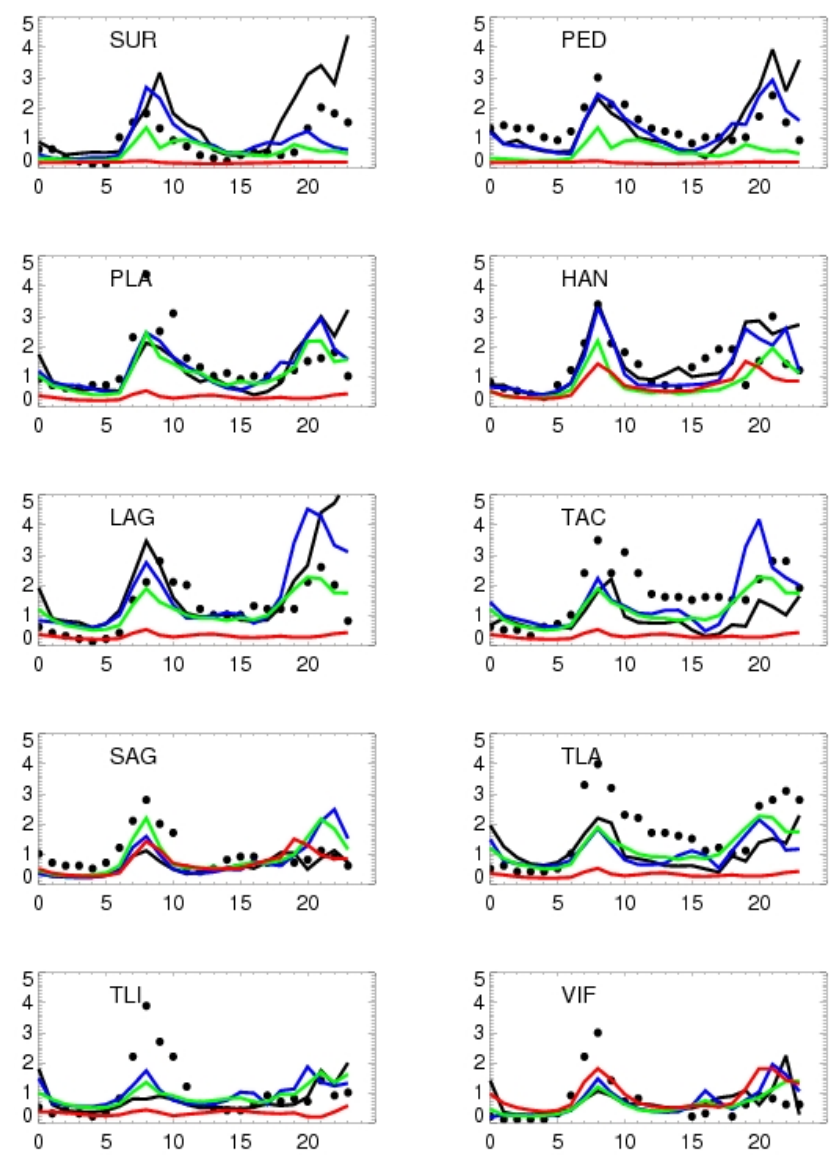

Fig. 5a. Calculated and measured surface diurnal variations for $\mathrm{CO}$ mixing ratio (ppmv) at various sites of Mexico City (shown in Table 1) in the different resolutions. Black lines represent the calculated value at $3 \mathrm{~km}$ resolution; blue lines for $6 \mathrm{~km}$ resolution; green lines for $12 \mathrm{~km}$ resolution, red lines for $24 \mathrm{~km}$ resolution. Black dots represent the measured values.

olution is not suitable for model calculations in the center of the city. At the north edge of the city (SAG, TLA, TLI, and VIF), the calculated CO concentrations are considerably improved compared to the situation at the city center, especially at the VIF site (far-north of the city and downwind of city plume), indicating that, at the edge of the city, the coarse resolution provides better results than the center of the city.

\subsection{Nitrogen oxides}

Figure $5 \mathrm{~b}$ shows the measured and calculated diurnal variations of surface $\mathrm{NO}_{\mathrm{x}}$ concentrations. In this case, the model shows that the $\mathrm{NO}_{\mathrm{x}}$ concentrations derived at different resolutions have diurnal variations similar to what is seen in the case of $\mathrm{CO}$. The main conclusion is that the calculated $\mathrm{NO}_{\mathrm{x}}$ concentrations are generally consistent with the measured $\mathrm{NO}_{\mathrm{x}}$ diurnal variation at 3,6 , and $12 \mathrm{~km}$ resolution. However, at $24 \mathrm{~km}$ resolution, the calculated $\mathrm{NO}_{\mathrm{x}}$ diurnal variation changes sharply, and the model significantly 

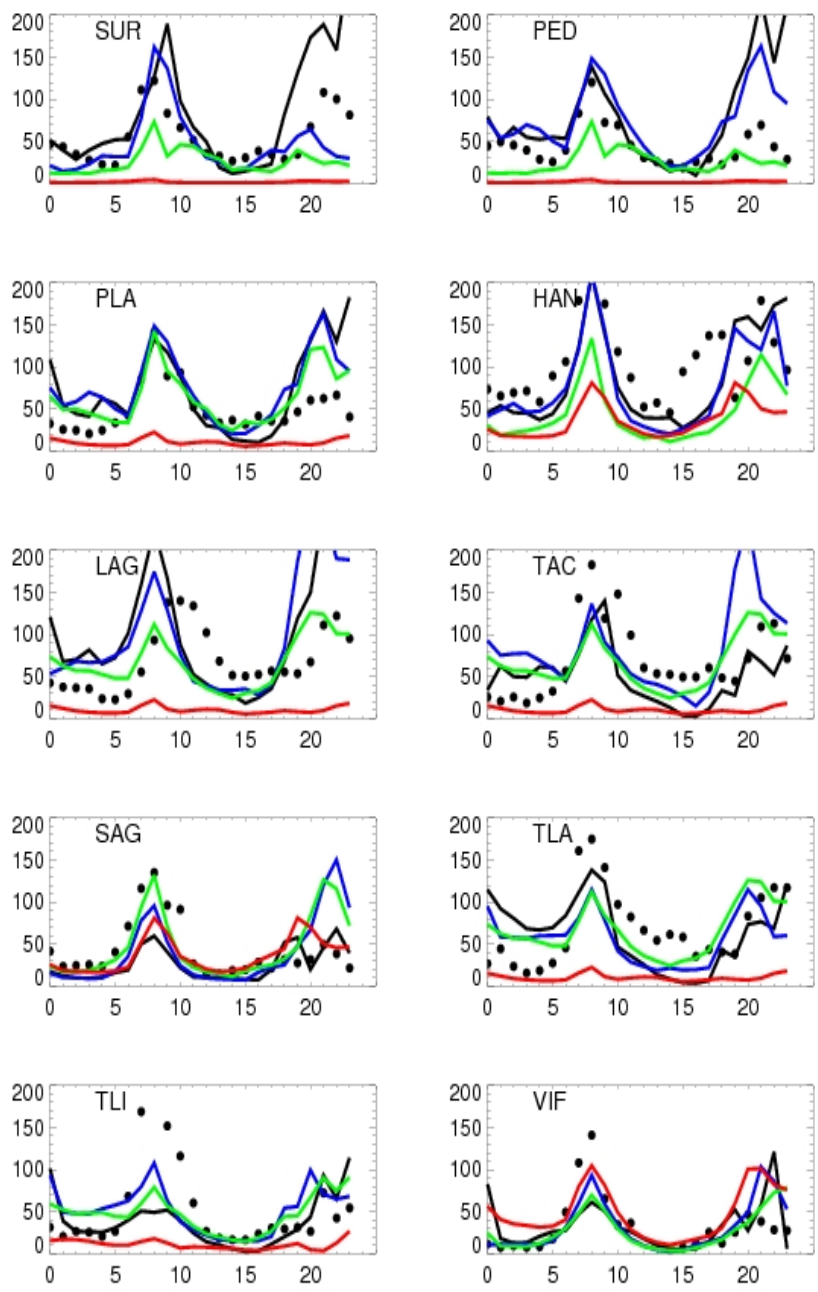

Fig. 5b. Same to Fig. 5a except for $\mathrm{NO}_{\mathrm{x}}$ (ppbv) diurnal variations.

underestimates the $\mathrm{NO}_{\mathrm{x}}$ measured values, especially at the center of the city. At the north edge of the city, the calculated $\mathrm{NO}_{\mathrm{x}}$ concentrations at coarse resolution are improved compared to the values derived at the city center, especially at the VIF site. Because both $\mathrm{CO}$ and $\mathrm{NO}_{\mathrm{x}}$ are directly emitted by surface sources, the calculation nearby the city sites is largely dependent upon the resolution of the adopted emission inventory. The $24 \mathrm{~km}$ resolution for emission and for the model is too coarse when applied to the regional model in Mexico City.

\subsection{Ozone}

Figure $5 \mathrm{c}$ shows the measured and calculated diurnal variations of surface $\mathrm{O}_{3}$ concentrations at the measurement sites. Unlike $\mathrm{CO}$ and $\mathrm{NO}_{\mathrm{x}}$, which are directly emitted from surface sources, $\mathrm{O}_{3}$ is photochemically produced and its chemical formation has a complicated non-linear relationship with $\mathrm{O}_{3}$ precursors (CO, NO, and VOCs). As a result, the different distributions of $\mathrm{O}_{3}$ precursors (such as $\mathrm{CO}$ and $\mathrm{NO}_{\mathrm{x}}$ ) derived
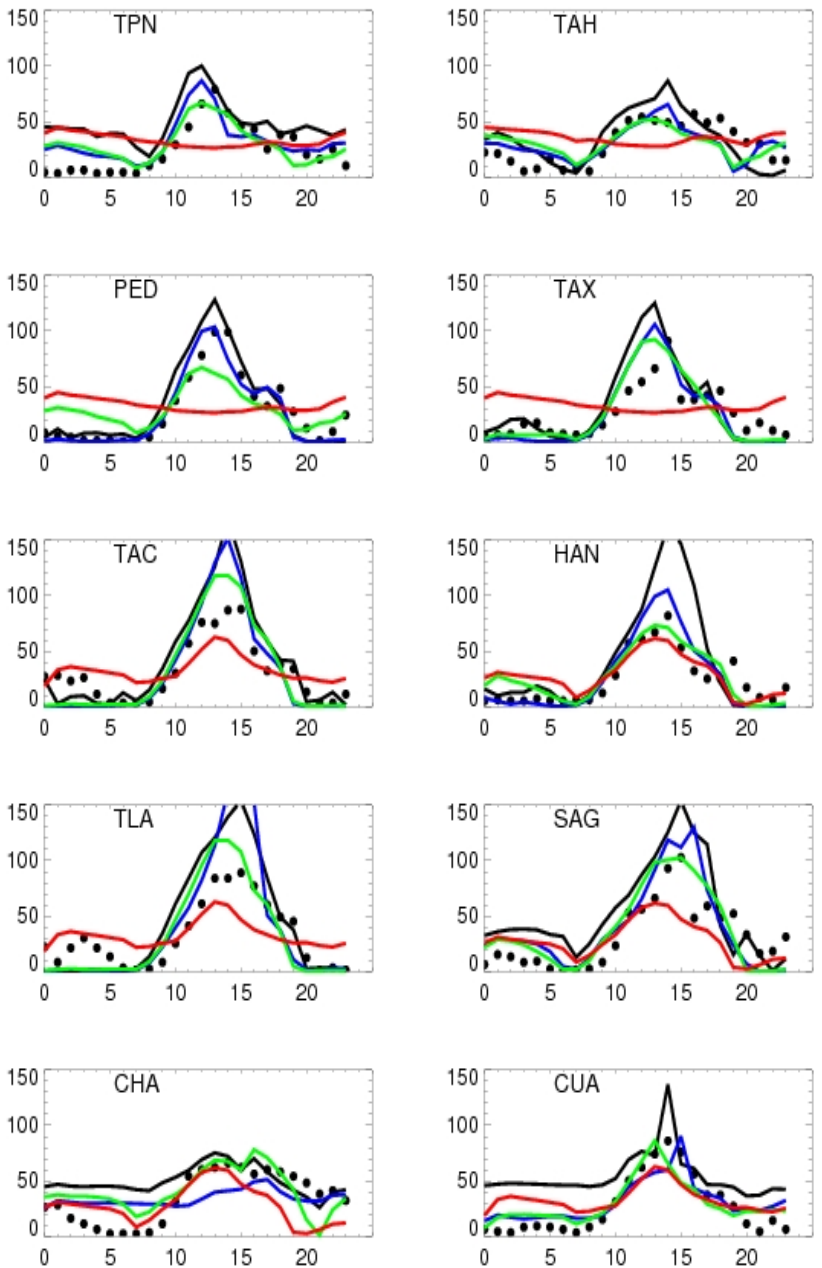

Fig. 5c. Same to Fig. 5a except for $\mathrm{O}_{3}$ (ppbv) diurnal variations.

with the different resolutions have important impacts on the calculated ozone distributions. For example, the calculated $\mathrm{O}_{3}$ concentrations at 3 and $6 \mathrm{~km}$ resolution are characterized by a strong maximum in the afternoon. This maximum is comparable to the measured $\mathrm{O}_{3}$ maximum. At the center of the city (TAC, HAN, and TLA), the calculated $\mathrm{O}_{3}$ maximum is higher than the measured $\mathrm{O}_{3}$ values. The calculated $\mathrm{O}_{3}$ minimum occurs in the morning when the 3,6 , and $12 \mathrm{~km}$ resolution are adopted, which is consistent with the measurements. However, the calculated $\mathrm{O}_{3}$ concentrations obtained at $24 \mathrm{~km}$ resolution are very different compared to the measured values, and are characterized by smaller diurnal variations. The maximum of $\mathrm{O}_{3}$ in the afternoon is significantly lower than the measured values downwind of the city and at the city center. The morning minimum is largely overestimated at these sites. Downwind of and at the edge of the city (such as CHA and CUA sites), the calculated $\mathrm{O}_{3}$ diurnal variations are closer to the observation that in the center of the city. 

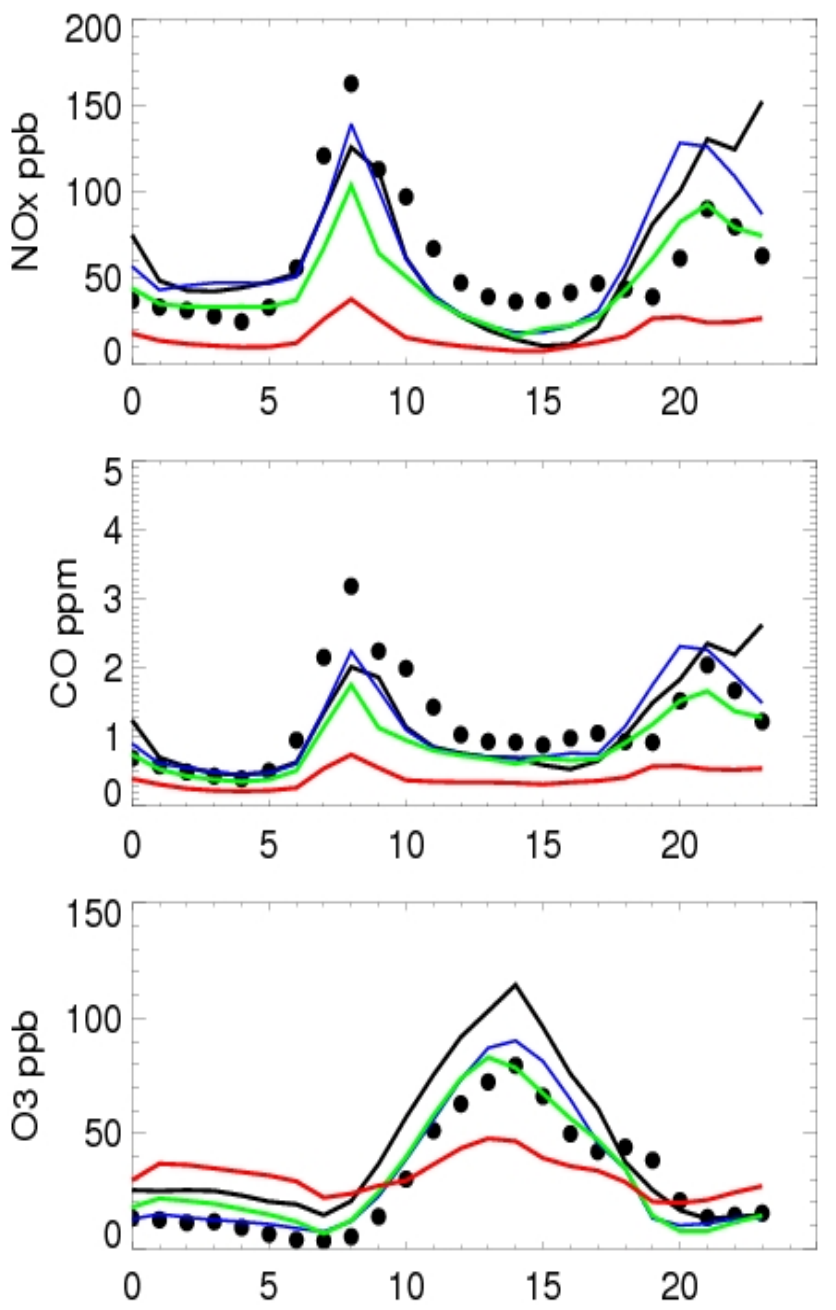

Fig. 6. Calculated and measured surface diurnal variations for $\mathrm{NO}_{\mathrm{x}}$ (upper panel), $\mathrm{CO}$ (middle panel), and $\mathrm{O}_{3}$ (lower panel). Averaged mixing ratios measured at selected sites in Mexico City. The black lines represent the calculated mixing ratios at $3 \mathrm{~km}$ resolution; the blue lines at $6 \mathrm{~km}$ resolution; the green lines at $12 \mathrm{~km}$ resolution, and the red lines at $24 \mathrm{~km}$ resolution. The black dots show the measured values.

\subsection{Diurnal variation and horizontal distribution}

Figure 6 shows that the mean diurnal variations of $\mathrm{CO}, \mathrm{NO}_{\mathrm{x}}$, and $\mathrm{O}_{3}$ averaged over all measurement sites. The calculated $\mathrm{NO}_{\mathrm{x}}$ diurnal variations are generally consistent with the measured values at the resolutions of 3,6 , and $12 \mathrm{~km}$. During early morning, the measured $\mathrm{NO}_{\mathrm{x}}$ concentrations are about $30 \mathrm{ppbv}$, and the calculated concentrations at 3 and $6 \mathrm{~km}$ resolution are slightly higher than the measured values. After 6 a.m., the measured $\mathrm{NO}_{\mathrm{x}}$ concentrations increase rapidly to reach a maximum of $160 \mathrm{ppbv}$ at $8 \mathrm{a} . \mathrm{m}$. By comparison, the calculated $\mathrm{NO}_{\mathrm{x}}$ maximum at 3 and $6 \mathrm{~km}$ resolution (140 ppbv) is close to the measured value. During daytime, the measured $\mathrm{NO}_{\mathrm{x}}$ concentrations are reduced to a minimum of $40 \mathrm{ppbv}$ due to a rapid increase in the PBL height (Tie et al., 2007). The calculated $\mathrm{NO}_{\mathrm{x}}$ mixing ratio at 3,6 , and $12 \mathrm{~km}$ resolution are also rapidly decreasing after 8 a.m. At $24 \mathrm{~km}$ resolution, there is a very weak diurnal variation and the calculated $\mathrm{NO}_{\mathrm{x}}$ concentrations are consistently lower than the measured values, especially during the morning hours. For example, the calculated morning maximum in the mixing ratio is about $30 \mathrm{ppbv}$, which is approximately $80 \%$ lower than the measured value (160 ppbv). The calculated mean $\mathrm{CO}$ diurnal variation is characterized by similar features than the calculated mean $\mathrm{NO}_{\mathrm{x}}$. In general, the calculated $\mathrm{CO}$ concentrations at $24 \mathrm{~km}$ resolution are significantly lower than the measured values, especially during the morning hours.

The averaged $\mathrm{O}_{3}$ diurnal cycle (shown in the lower panel of Fig. 6) is different from the averaged $\mathrm{CO}$ and $\mathrm{NO}_{\mathrm{x}}$ diurnal variations. In the case of ozone, the cycle exhibits a minimum in the morning (at $7 \mathrm{AM}$ ) and a maximum in the afternoon (at 2 p.m.). The calculated $\mathrm{O}_{3}$ concentrations at 3,6 , and $12 \mathrm{~km}$ exhibit a similar diurnal variation. However, the calculated $\mathrm{O}_{3}$ concentrations at $3 \mathrm{~km}$ resolution are higher than the measured values, especially during the afternoon (by about $35 \%$ ). By contrast, the $\mathrm{O}_{3}$ diurnal variation derived at $24 \mathrm{~km}$ resolution is very different from the measured diurnal variation. The $\mathrm{O}_{3}$ concentrations calculated during daytime (from 8 a.m. to 19 p.m.) are consistently lower than the measured values. For example, at 2 p.m., the calculated $\mathrm{O}_{3}$ concentration is equal to $45 \mathrm{ppbv}$, which is about $45 \%$ lower than the measured value $(80 \mathrm{ppbv})$. The calculated concentrations during nighttime (from 6 p.m. to 7 a.m.) are consistently higher than the observations. Since the diurnal variation of ozone is strongly regulated by the chemical precursors in large cities (Zhang et al., 2004), the small ozone diurnal variation calculated at $24 \mathrm{~km}$ resolution suggests that the concentrations of $\mathrm{O}_{3}$ precursors are underestimated by the model in the urban area. This is consistent with the calculated concentrations of $\mathrm{CO}$ and $\mathrm{NO}_{\mathrm{x}}$ as represented in the upper and middle panels of Fig. 6.

The results presented above clearly indicate that there is a threshold value in the model resolution under which the discrepancy between calculated and observed concentrations becomes larger than acceptable, especially in large urban areas. In our study, the concentrations of ozone and its precursors change considerably when the model resolution changes from 12 to $24 \mathrm{~km}$. Specially, a resolution of $24 \mathrm{~km}$ is not suitable for calculating the distributions of air pollutants in Mexico City. At 12 and $24 \mathrm{~km}$ resolution, the ratios of the city boundary (about $70 \mathrm{~km}$ in length and width) to the size of the horizontal grid are about 6 to 1 and 3 to 1 , respectively. The threshold value for the model resolution is therefore approximately $12 \mathrm{~km}$, which implies that the ratio between the size of the city and the grid size of the model should be at least a factor of 6 to 1 . 
Table 2. The information regarding the model runs at different resolutions.

\begin{tabular}{lll}
\hline & Resolution & Note \\
\hline Run-1 & $3 \mathrm{~km}$ & Emission $(3 \mathrm{~km})$ and Grid $(3 \mathrm{~km})$ \\
Run-2 & $6 \mathrm{~km}$ & Emission $(6 \mathrm{~km})$ and Grid $(6 \mathrm{~km})$ \\
Run-3 & $12 \mathrm{~km}$ & Emission $(12 \mathrm{~km})$ and Grid $(12 \mathrm{~km})$ \\
Run-4 & $24 \mathrm{~km}$ & Emission $(24 \mathrm{~km})$ and Grid $(24 \mathrm{~km})$ \\
Run-5 & $6 \mathrm{~km}$ & Emission $(24 \mathrm{~km})$ and Grid $(6 \mathrm{~km})$ \\
\hline
\end{tabular}

\section{Discussion of results}

The above discussion shows that the model resolution has very strong impacts on the calculated concentration of ozone and its precursors in urban areas. As highlighted and illustrated Fig. 1, the impact of model resolution on the calculated $\mathrm{O}_{3}$ and $\mathrm{O}_{3}$ precursor concentrations can be attributed to three main factors; (1) the spatial resolution of the surface emission of ozone precursors, (2) the resolution of meteorological fields, and (3) the effect of resolution on the calculated photochemical ozone production and destruction rates. In order to study the individual contribution to these three factors, five model simulations are performed. They are listed in Table 2. In Run-1 through Run-4, the model resolution varies from 3 to $24 \mathrm{~km}$, and the changes in the calculated concentration of ozone and its precursors are due to the combination of all these three factors. In Run-5, the model resolution is set at $6 \mathrm{~km}$ resolution, except for the emissions, for which the resolution is equal to $24 \mathrm{~km}$. Thus, the difference between Run-5 and Run-2 is mainly due to the difference of emission resolution, while the difference between Run- 5 and Run- 4 is mainly due to the difference in the resolution adopted for the calculated meteorological conditions.

\subsection{The effects of meteorological conditions at different resolutions}

Figure 7 shows the calculations of the $\mathrm{CO}$ surface distributions obtained for Run-2, Run-4, and Run-5. Because CO is only weakly chemically reactive, the calculated $\mathrm{CO}$ distribution derived after a few days of integration is affected by the spatial resolution of transport processes (driven by the calculated meteorological conditions, such as wind direction and speed) and of surface emissions. As shown in Fig. 7, there are very large differences between the results of Run-5 and Run-4, suggesting the importance of the spatial resolution adopted for the simulation of transport processes. For example, the detailed wind pattern calculated in Run-5 ( $6 \mathrm{~km}$ grid) cannot be resolved in Run-4 (24 km grid). There are also indications that the mountain breeze at the west and east edges of Mexico City is resolved in a grid size of $6 \mathrm{~km}$ but not of $24 \mathrm{~km}$. These detailed wind distributions play important roles in distributing the $\mathrm{CO}$ that is emitted from the city sources. In addition, the calculated $\mathrm{CO}$ concentrations
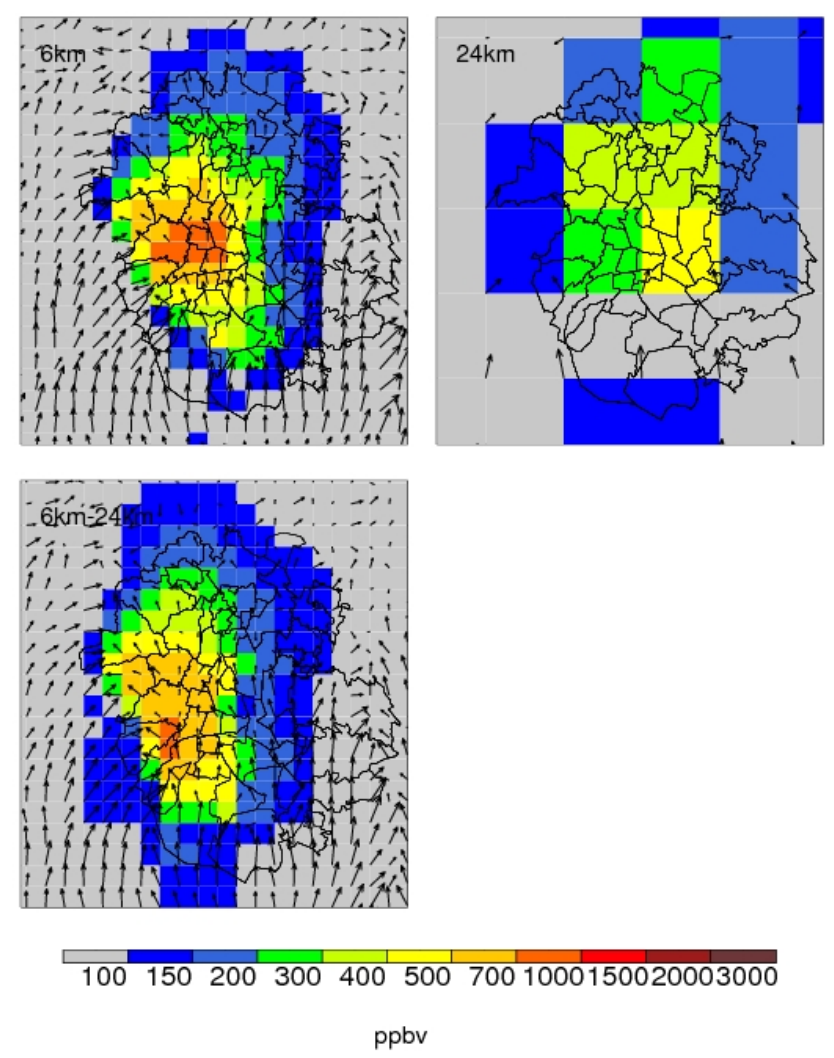

Fig. 7. Calculated surface distributions of the CO mixing ratio (ppbv) in Mexico City with wind patterns at different resolutions. Run-2 corresponds to $6 \mathrm{~km}$ resolution, Run- 4 to $24 \mathrm{~km}$ resolution, and Run-5 to $6 \mathrm{~km}$ resolution with 24 emission resolution.

at $24 \mathrm{~km}$ resolution tend to be diluted in the large urban area $\left(576 \mathrm{~km}^{2}\right)$, leading to reduced CO concentrations in the center of city and enhanced $\mathrm{CO}$ concentrations in the edge of the city area (see Fig. 7).

\subsection{The effects of emission inventory at different resolutions}

As shown in Table 2, the differences between Run-2 and Run-5 provide information on the effect of the resolution associated only with surface emissions $(6 \mathrm{~km}$ in Run- 2 and $24 \mathrm{~km}$ in Run-5). The overall model resolution is the same in both cases. Figure 7 shows that the distribution of the CO surface concentration is considerably improved in Run5 compared to Run- 4 , suggesting that more accurate meteorological parameters improves the $\mathrm{CO}$ distributions in the center of the city. However, there are also clear differences between Run-2 and Run-5. Thus, the resolution at which the emissions are provided, has also a significant impact on the calculated $\mathrm{CO}$ distributions. For example, the maximum $\mathrm{CO}$ density at the center of city is reduced from 1000 to $700 \mathrm{ppbv}$, when higher resolution emissions are adopted. There are also indications that the $\mathrm{CO}$ distributions obtained with Run-5 are 

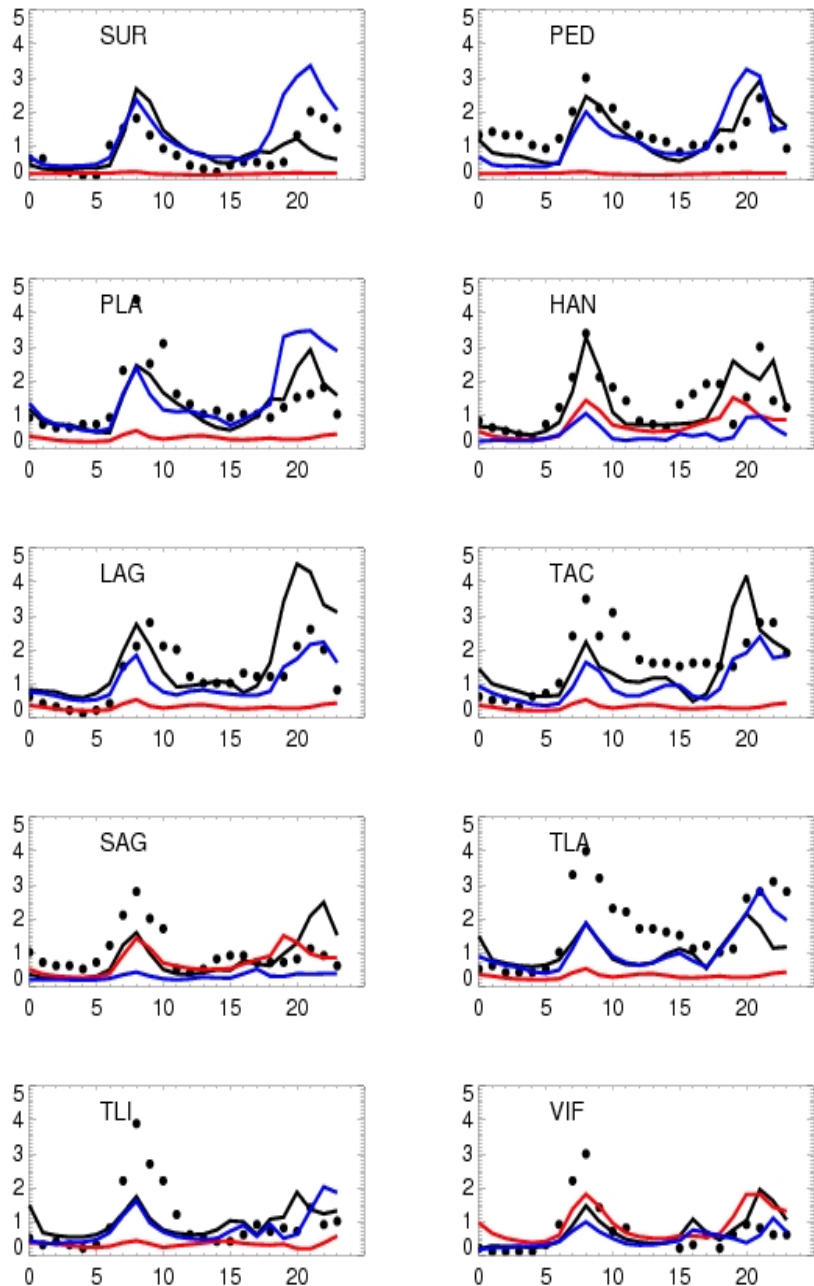

Fig. 8. Calculated and measured CO diurnal variations in the surface mixing ratio (ppmv) at different sites (shown in Table 1) for different resolutions in Mexico City. The black lines represent the mixing ratio calculated in Run-2; the blue lines represent the values calculated in Run-5; the red lines represent the values calculated in Run-4. The black dots represent the measured values.

more spatially mixed than with Run-2. However, the model results seem to be more sensitive to the atmospheric resolution of dynamics and photochemistry than to the resolution of surface emissions. As shown by Fig. 8, the diurnal variations in the $\mathrm{CO}$ concentrations, especially at the center of the city (such as SUR, PED, PLA, and LAG sites), are improved when the high model resolution $(6 \mathrm{~km})$ and the coarse resolution in emissions $(24 \mathrm{~km})$ are adopted. The calculated values are still lower than the measured concentrations at other sites (such as HAN and SAG).

\subsection{The effects of ozone photochemistry}

As we described above, ozone, a secondary pollutant, is not directly emitted from surface sources, but is closely related to the concentration of its precursors (including $\mathrm{CO}, \mathrm{NO}_{\mathrm{x}}$, and VOCs). Thus, the calculated $\mathrm{O}_{3}$ distributions are not directly dependent upon the resolution of the emission inventories, but are indirectly related to the resolution of precursor emissions. Because the ozone formation rate is a nonlinear function of $\mathrm{O}_{3}$ precursors (Lin et al., 1988; Kleinman, 2000), the chemical production rate of ozone is a function of model resolution.

In order to get insights of the effects of resolution on ozone photochemistry, ozone chemical productions are calculated for Run-2, Run-4, and Run-5. The ozone chemical production is initiated by the oxidization of $\mathrm{CO}$ and VOCs, which leads to the production of $\mathrm{HO}_{2}$ and $\mathrm{RO}_{2}$ radicals. In the presence of $\mathrm{NO}$, ozone is produced by the following reaction chain (Brasseur et al., 1999):

$$
\begin{aligned}
& \mathrm{HO}_{2}+\mathrm{NO} \rightarrow \mathrm{NO}_{2}+\mathrm{OH} \\
& \mathrm{RO}_{2}+\mathrm{NO} \rightarrow \mathrm{NO}_{2}+\mathrm{RO} \\
& \mathrm{NO}_{2}+h v \rightarrow \mathrm{NO}+\mathrm{O} \\
& \mathrm{O}+\mathrm{O}_{2} \rightarrow \mathrm{O}_{3}
\end{aligned}
$$

From Reactions (R1) and (R4), the $\mathrm{O}_{3}$ chemical production rate is expressed by

$$
\begin{aligned}
& P\left(\mathrm{O}_{3}\right)=P_{\mathrm{HO}_{2}}\left(\mathrm{O}_{3}\right)+P_{\mathrm{RO}_{2}}\left(\mathrm{O}_{3}\right) \\
& P_{\mathrm{HO}_{2}}\left(\mathrm{O}_{3}\right)=k_{1} \times\left(\mathrm{HO}_{2}\right)(\mathrm{NO}) \\
& P_{\mathrm{RO}_{2}}\left(\mathrm{O}_{3}\right)=\Sigma k_{2 i} \times\left(\mathrm{RO}_{2}\right)_{i}(\mathrm{NO})
\end{aligned}
$$

where $P\left(\mathrm{O}_{3}\right)$ represents the total rate of $\mathrm{O}_{3}$ production and $P_{\mathrm{HO}_{2}}\left(\mathrm{O}_{3}\right)$ and $P_{\mathrm{RO}_{2}}\left(\mathrm{O}_{3}\right)$ the rate of $\mathrm{O}_{3}$ production due to the oxidation of $\mathrm{NO}$ by $\mathrm{HO}_{2}$ and $\mathrm{RO}_{2}$, respectively. Note that $\mathrm{RO}_{2}$ stands for several types of peroxy radicals that are produced by the oxidation of VOCs by the $\mathrm{OH}$ radical. The parameters of $k_{1}$, and $k_{2 i}$ are the rate coefficients for Reactions (R1) and (R2), respectively.

Figure 9 shows the calculated noontime rate of photochemical ozone production $P\left(\mathrm{O}_{3}\right)$ (ppbv/hour) with Run-1, Run-2, Run4, and Run-5, respectively. These graphs show that the distribution of $P\left(\mathrm{O}_{3}\right)$ is generally similar for Run1 and Run-2 with a maximum value of 50-60 ppbv/hour at the center of the city. However, it appears that the $\mathrm{O}_{3}$ distribution of Run-1 has a finer structure than in the case of Run-2 due to the finer resolution of the model. The distribution of $P\left(\mathrm{O}_{3}\right)$ produced by Run-4 is very different than in Run-1 and Run-2, highlighting that the coarse resolution $(24 \mathrm{~km})$ is not suitable for performing ozone chemical studies in urban areas. The calculated $P\left(\mathrm{O}_{3}\right)$ has a maximum (30-40 ppbv/hour) in the northwestern area of the city rather than in the center of the city (as shown in Run-1 and Run-2). As a result, the calculated $\mathrm{O}_{3}$ diurnal variations are close to the measured values at these sites (such as HAN, SAG, and CHA), but are largely underestimated when compared to the 
Table 3. Statistics of the model performance for different model resolution.

\begin{tabular}{|c|c|c|c|c|c|}
\hline \multicolumn{6}{|c|}{$\mathrm{CO}$ (ppmv) } \\
\hline & Mean & Min & Ma & $\Delta($ Mean $)$ & $\Delta(\operatorname{Max})$ \\
\hline Measured & 1.22 & 0.10 & 4.40 & & \\
\hline $3 \mathrm{~km}$ & 1.15 & 0.21 & 5.48 & -0.07 & 1.08 \\
\hline $6 \mathrm{~km}$ & 1.12 & 0.17 & 4.54 & -0.10 & 0.14 \\
\hline $12 \mathrm{~km}$ & 0.89 & 0.21 & 2.44 & -0.33 & -1.96 \\
\hline $24 \mathrm{~km}$ & 0.40 & 0.11 & 1.80 & -0.82 & -2.60 \\
\hline $6 \mathrm{~km} *$ & 0.90 & 0.16 & 3.48 & -0.32 & -0.92 \\
\hline \multicolumn{6}{|c|}{$\mathrm{NO}_{\mathrm{X}}(\mathrm{ppbv})$} \\
\hline & Mean & Min & $\operatorname{Max}$ & $\Delta$ (Mean) & $\Delta(\operatorname{Max})$ \\
\hline Measured & 60.0 & 7.0 & 277.0 & & \\
\hline $3 \mathrm{~km}$ & 64.6 & 2.0 & 311.8 & 4.6 & 34.8 \\
\hline $6 \mathrm{~km}$ & 63.8 & 3.2 & 257.1 & 3.8 & -19.9 \\
\hline $12 \mathrm{~km}$ & 48.2 & 3.1 & 142.5 & -11.8 & -134.5 \\
\hline $24 \mathrm{~km}$ & 16.9 & 0.1 & 104.6 & -43.1 & -172.3 \\
\hline $6 \mathrm{~km}^{*} 47.6$ & 0.9 & 194.5 & -12.3 & -82.4 & \\
\hline \multicolumn{6}{|c|}{$\mathrm{O}_{3}$ day $(\mathrm{ppbv})$} \\
\hline Mean & Min & Max & $\Delta$ (Mean) & $\Delta(\operatorname{Max})$ & \\
\hline Measured & 43.1 & 1.0 & 103.0 & & \\
\hline $3 \mathrm{~km}$ & 67.4 & 2.0 & 169.6 & 24.2 & 66.6 \\
\hline $6 \mathrm{~km}$ & 52.4 & 1.0 & 192.6 & 9.2 & 89.6 \\
\hline $12 \mathrm{~km}$ & 49.4 & 1.5 & 118.5 & 6.3 & 15.5 \\
\hline $24 \mathrm{~km}$ & 35.0 & 8.0 & 62.6 & -8.1 & -40.3 \\
\hline $6 \mathrm{~km} *$ & 58.1 & 1.3 & 189.1 & 15.0 & 86.7 \\
\hline \multicolumn{6}{|c|}{$\mathrm{O}_{3}$ night (ppbv) } \\
\hline Mean & Min & $\operatorname{Max}$ & $\Delta$ (Mean) & $\Delta(\operatorname{Max})$ & \\
\hline Measured & 16.3 & 0.1 & 58.0 & & \\
\hline $3 \mathrm{~km}$ & 21.9 & 0.1 & 48.7 & 5.6 & -9.2 \\
\hline $6 \mathrm{~km}$ & 13.8 & 0.1 & 44.4 & -2.4 & -13.5 \\
\hline $12 \mathrm{~km}$ & 16.4 & 0.1 & 38.7 & 0.2 & 0.7 \\
\hline $24 \mathrm{~km}$ & 28.8 & 2.1 & 44.7 & 12.4 & -13.2 \\
\hline $6 \mathrm{~km} *$ & 23.2 & 0.1 & 72.5 & 6.9 & 14.5 \\
\hline \multicolumn{6}{|c|}{ Temperature $\left({ }^{\circ} \mathrm{C}\right)$} \\
\hline Mean & Min & Max & $\Delta$ (Mean) & $\Delta(\operatorname{Max})$ & \\
\hline Measured & 14.9 & 6.9 & 26.4 & & \\
\hline $3 \mathrm{~km}$ & 14.9 & 10.8 & 20.4 & 0.02 & -5.9 \\
\hline $6 \mathrm{~km}$ & 15.0 & 10.9 & 19.5 & 0.08 & -6.8 \\
\hline $12 \mathrm{~km}$ & 13.8 & 6.8 & 20.1 & -1.1 & -6.2 \\
\hline $24 \mathrm{~km}$ & 11.5 & 5.8 & 19.2 & -3.3 & -7.1 \\
\hline
\end{tabular}

$6 \mathrm{~km}^{*}$ represents the model simulation with $6 \mathrm{~km}$ in model grid and with $24 \mathrm{~km}$ in emission resolution. $\Delta$ (Mean) is equal to Mean $_{\text {model }}-$ Mean $_{\text {measured }} \Delta($ Max) is equal to $\mathrm{Max}_{\text {model }}-\mathrm{Max}_{\text {measured }}$.

values measured in the center of the city, and in the southern area (such as TPN, TAH, PED, and TAX). At these sites, the calculated ozone production rates are very low, and the afternoon ozone concentration maxima are significantly underestimated when compared to the measured diurnal variations (see Fig. 9). Run-4 also suggests that the calculated ozone production is diluted outside the city due to the large grid cell $\left(576 \mathrm{~km}^{2}\right)$. For example, at the west edge of the city, the ozone production rate is about $10-15 \mathrm{ppbv} /$ hour in Run-5, while it is less than 5 ppbv/hour in the finer resolution calculations (Run-1 and Run-2).
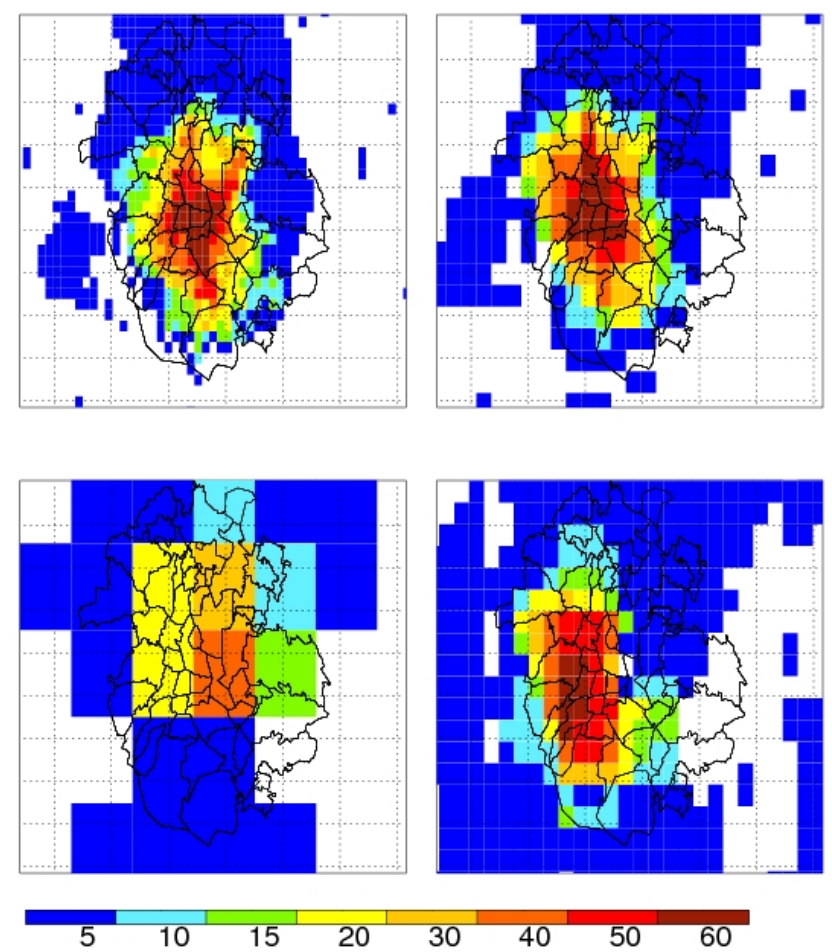

Fig. 9. Calculated surface distributions of the $\mathrm{O}_{3}$ production rate (ppbv/hour) (see Eq. 1) in Mexico City from Run-1 (3 km resolution), Run-2 (6 km resolution), Run-4 (24 km resolution), and Run5 (6 km resolution with 24 emission resolution).

The calculation of the $\mathrm{O}_{3}$ production is considerably improved in Run-5 compared to Run-4, even though both calculations use the same spatial resolution for the surface emission rates $(24 \mathrm{~km})$. However, with the finer grid of Run-5, the distribution of $P\left(\mathrm{O}_{3}\right)$ is similar to the results obtained in Run-1 and Run-2. The $P\left(\mathrm{O}_{3}\right)$ maximum at the center of the city is about 50-60 ppbv/hour, which is similar to the values provided by Run-1 and Run-2. As a result, the calculation of the $\mathrm{O}_{3}$ diurnal variations is also considerably improved when compared to the measured values. In this case, the diurnal variation in the ozone concentration is better represented, especially at the southern and city sites (TPN, TAH, PED and TAX). The ozone diurnal variation derived in Run-4 is significantly underestimated at these sites (see Fig. 10).

\subsection{Overall discussion}

In order to gain some integrated insights of the effects of model resolution on the calculated $\mathrm{CO}, \mathrm{NO}_{\mathrm{x}}$, and $\mathrm{O}_{3}$ concentrations, the measured and calculated $\mathrm{CO}, \mathrm{NO}_{\mathrm{x}}$, and $\mathrm{O}_{3}$ concentrations are averaged at all sites as shown in Table 3 and Fig. 11. In addition to the mean values, the minimum and maximum concentrations of these chemicals are also highlighted in Table 3 and Fig. 11. The range between the minimum and maximum concentrations provides useful 

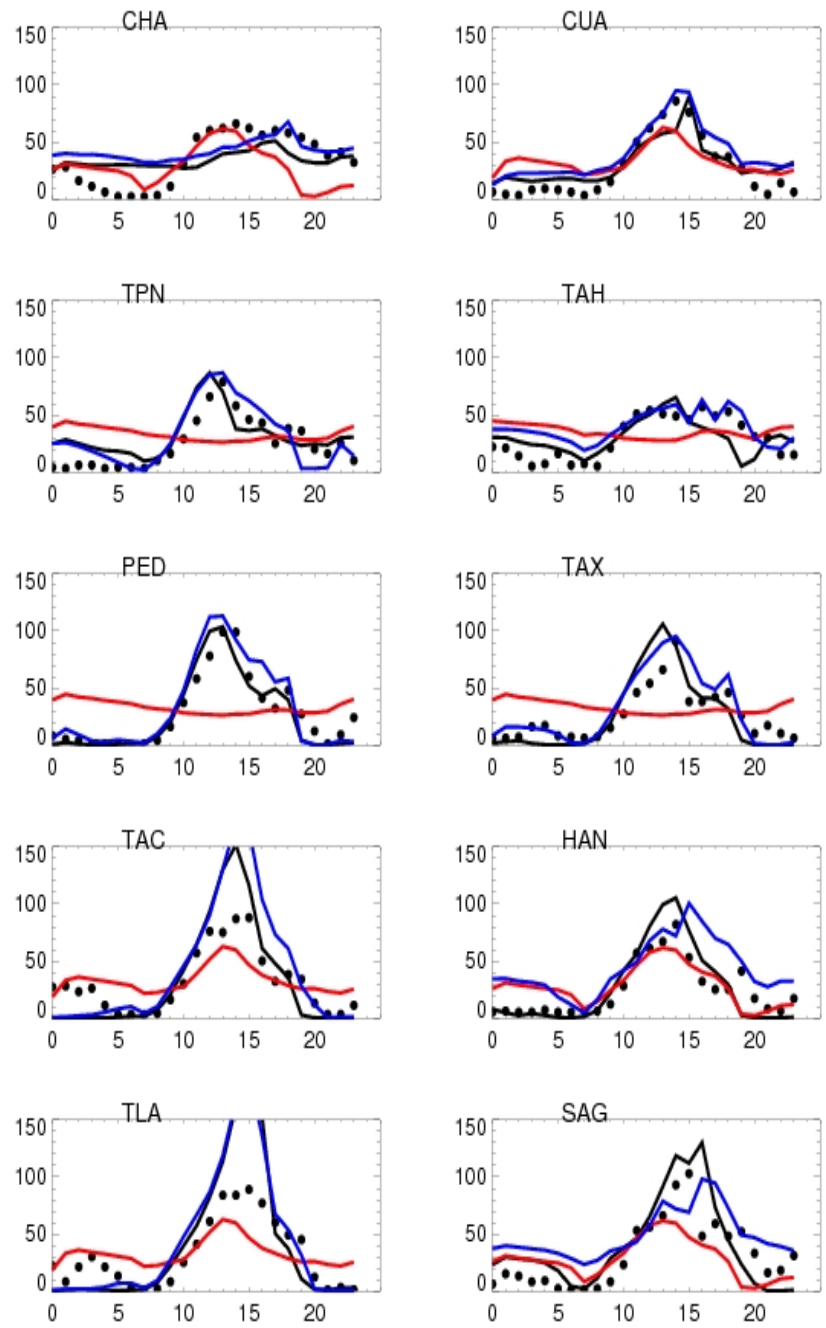

Fig. 10. Calculated and measured diurnal variations in surface ozone mixing ratio at different resolutions in Mexico City. The black lines represent the calculated mixing ratio from Run-2; the blue lines the calculated result from Run-5; the red lines the calculated result from Run- 4 . The black dots represent the measured values.

information on the variability of measured and calculated concentrations. The model shows that the mean measured $\mathrm{NO}_{\mathrm{x}}$ concentrations reach $60 \mathrm{ppbv}$, which is close to the $\mathrm{NO}_{\mathrm{x}}$ concentrations calculated at 3 and $6 \mathrm{~km}$ resolution. Both the average and the variability of $\mathrm{NO}_{\mathrm{x}}$ concentration calculated at $12 \mathrm{~km}$ resolution $(48 \mathrm{ppbv})$ are lower than the measured values, but the average $\mathrm{NO}_{\mathrm{x}}$ concentration obtained at $24 \mathrm{~km}$ resolution is significantly lower $(70 \%)$ than the measured value. It appears therefore that $12 \mathrm{~km}$ is a threshold resolution for the calculation of $\mathrm{NO}_{\mathrm{x}}$ distribution in Mexico City.

The average $\mathrm{CO}$ concentrations (middle panel) are characterized by features that are similar to those of the average $\mathrm{NO}_{\mathrm{x}}$ concentrations. The model shows that the calculated $\mathrm{CO}$ concentrations at 3 and $6 \mathrm{~km}$ resolution are most repre-
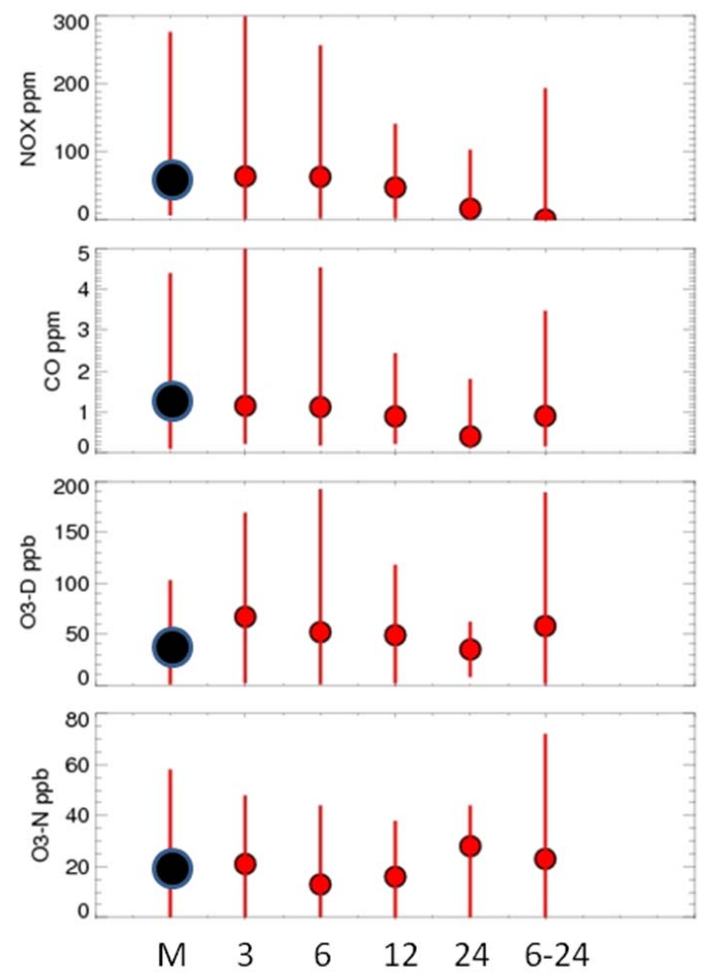

Fig. 11. Calculated and measured mean surface concentrations for $\mathrm{NO}_{\mathrm{x}}$ (ppbv), $\mathrm{CO}$ (ppmv), day-time $\mathrm{O}_{3}$ (ppbv), and night-time $\mathrm{O}_{3}$ (ppbv) averaged at the measurement sites for different model resolutions in Mexico City. The vertical bars indicate the range between minimum and maximum values (variability) of concentrations.

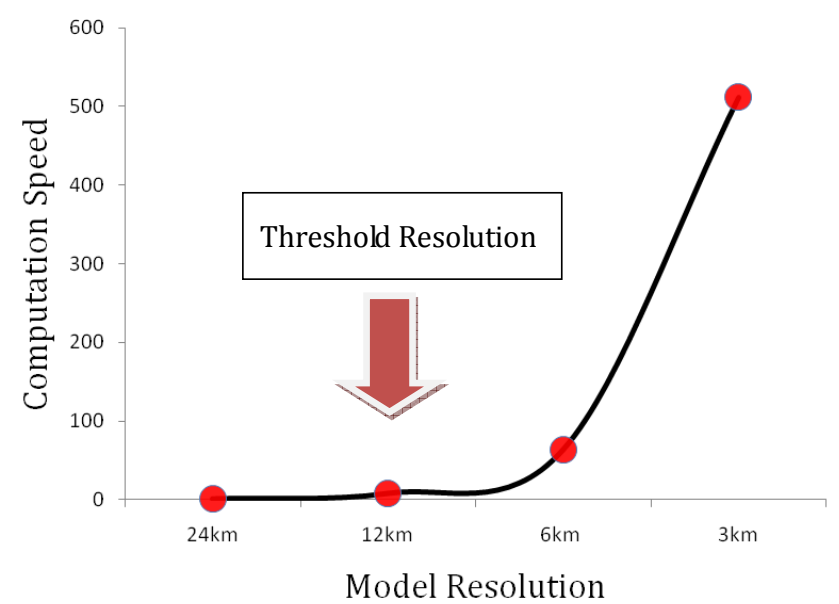

Fig. 12. Relationship between the WRF-Chem model resolution and computation time required for the each individual calculation.

sentative of the measured values. Both the calculated average and variability of $\mathrm{CO}$ concentration at $12 \mathrm{~km}$ resolution is lower than the measured value, while the calculated average $\mathrm{CO}$ concentration at $24 \mathrm{~km}$ resolution is significantly lower than the measured value. This result confirms that $12 \mathrm{~km}$ 
resolution is the threshold value for the calculation of $\mathrm{CO}$ distribution in Mexico City.

Ozone chemistry is very different during daytime and nighttime (Sillman, 1995; Zhang et al., 2004). As a result, the $\mathrm{O}_{3}$ concentrations are separately averaged for daytime ( 8 a.m. to 19 p.m.) and nighttime (20 p.m. to 7 a.m.). The mean measured $\mathrm{O}_{3}$ daytime concentration is about $45 \mathrm{ppbv}$, which is close to the calculated $\mathrm{O}_{3}$ concentrations at 6 and $12 \mathrm{~km}$ resolution. The calculated $\mathrm{O}_{3}$ concentration at $3 \mathrm{~km}$ resolution overestimates the measured value. The average daytime ozone density calculated at $24 \mathrm{~km}$ resolution is lower than the measured value by about $35 \%$. Interestingly, the measured ozone concentrations are characterized by a very large difference $(30 \mathrm{ppbv})$ between the daytime and nighttime values. The calculated $\mathrm{O}_{3}$ concentrations with 3,6 , and $12 \mathrm{~km}$ also exhibit a large daytime to nighttime difference. This difference, however, is limited to only $6 \mathrm{ppbv}$ when $24 \mathrm{~km}$ is adopted for the model resolution. The small difference between day and night for this resolution suggests that both the day and night $\mathrm{O}_{3}$ chemistries cannot be well calculated at $24 \mathrm{~km}$ resolution, resulting in a poorly simulated $\mathrm{O}_{3}$ diurnal variation. The main reason is that ozone formation is strongly regulated by $\mathrm{NO}_{\mathrm{x}}$ concentrations, which is not reasonably simulated at $24 \mathrm{~km}$. This is a further confirmation that the threshold resolution for the calculation of $\mathrm{O}_{3}$ is at $12 \mathrm{~km}$.

Regional chemical/dynamical models (such as the WRFChem model) require a large amount computation time. The reduction in the number of model grid points (decreasing model resolution) can reduce the computation burden needed for the model integration. As indicated in Fig. 12, increasing the resolution from $24 \mathrm{~km}$ to $3 \mathrm{~km}$ leads to an increase in the computation burden of a factor 512. However, increasing the resolution from $24 \mathrm{~km}$ to $6 \mathrm{~km}$ only requires an increase of a factor 64 . From the above analysis, the threshold resolution for accurate simulation in an urban area like Mexico City is $12 \mathrm{~km}$. An appropriate spatial resolution that balances model performance and computation burden is of the order of $6 \mathrm{~km}$. This resolution appears to be optimal for the calculation of ozone and its precursors in Mexico City.

\section{Summary}

The effects of model resolution (including grid resolution and emission inventory resolution) on the calculated $\mathrm{CO}$, $\mathrm{NO}_{\mathrm{x}}$, and $\mathrm{O}_{3}$ distributions are investigated by applying the WRF-Chem chemical/dynamical model to the area around Mexico City. This study focuses on the threemajor issues associated with the impacts of model resolution on the calculated $\mathrm{O}_{3}$ formation. The three issues are: (1) spatial resolution for meteorological fields; (2) spatial resolution associated with surface emission; and (3) non-linearity in the ozone chemistry and specially in the calculated $\mathrm{O}_{3}$ production rate. In this study, five model simulations are performed to study the above effects, including Run-1 ( $3 \mathrm{~km}$ resolution), Run-2 (6 km resolution), Run-3 (12 km resolution), Run-4 ( $24 \mathrm{~km}$ resolution), and Run-5 (6 km grid resolution with $24 \mathrm{~km}$ emission inventory resolution). The different simulations show that the model resolution has important effects on the calculated concentrations of ozone and its chemical precursors in a dense urban area such as Mexico City. The $\mathrm{CO}, \mathrm{NO}_{\mathrm{x}}$, and $\mathrm{O}_{3}$ surface concentrations calculated at 3 and $6 \mathrm{~km}$ resolution reasonably simulate the measured concentrations in Mexico City. Slight underestimations of the calculated concentrations occur at $12 \mathrm{~km}$ resolution. When the model resolution decreases to $24 \mathrm{~km}$, the model performance becomes very poor compared to the values measured in Mexico City, suggesting that there is a threshold value for model resolution for the calculations of ozone and its precursors. In our case, the suggested threshold value is $12 \mathrm{~km}$. When the model resolution is lower than the threshold resolution, the calculated concentrations are very different from the measured values. The ratio of the city boundary (about $70 \mathrm{~km}$ in length and width) to the threshold resolution is 6 to 1 . This ratio can be considered as a test value in other urban areas for model resolution setting. The most important factor required to maintain the threshold ratio $(6: 1)$ in model resolution is due to the calculation of meteorological parameters and transport of chemical pollutants. When model resolution is lower than the threshold ratio, the calculated meteorological parameters cannot be properly represented, resulting in poor representation of horizontal distributions of ozone and air pollutants. The effects of emission inventory and photochemistry also play important roles on the calculated distributions of air pollutants under different resolutions, and better simulations can be obtained when the resolution of emission inventory is lower than the threshold ratio. However, the effects of the resolution of emission inventory and photochemistry on the calculated distributions of ozone and other air pollutants are smaller than the effect of meteorological calculation. It notes that, for each individual large city, model calculations should be performed to confirm this hypothesis.

The present study suggests that the largest impacts of model resolution on the calculated $\mathrm{O}_{3}$ and its precursors are associated with changes in meteorological conditions and the transport processes. The changes due to the emission resolution have modest impact on the calculated concentrations. Finally, this study suggests that the model resolution has important impacts on $\mathrm{O}_{3}$ chemical formation due to the nonlinear relationship between $\mathrm{O}_{3}$ formation and $\mathrm{O}_{3}$ precursors.

Acknowledgements. The authors would like to thank George Grell and Steve Peckham at NOAA for providing us with the WRF-Chem model. We wish to thank Jim Greenburg for helpful discussions. The National Center for Atmospheric Research is sponsored by the National Science Foundation.

Edited by: L. Molina 


\section{References}

Brasseur, G., Orlando, J., and Tyndall, G.: Atmospheric Chemistry and Global Change, Oxford University Press, 90-120, 1999.

Cairns M. M. and Corey, J.: An application of the MM5 to modeling high winds in complex terrain: A case study in the eastern Sierra, Western Region Tech. Attachment 98-13, 4 pp., 1998.

Chameides, W. L. and Walker, J.: Time dependent photochemical model for ozone near the ground, J. Geophys. Res., 81, 413-420, 1976.

Colle B. A., Mass, C. F., and Westrick, K. J.: MM5 precipitation verification over the Pacific Northwest during the 1997-99 cool seasons, Weather Forecast., 15, 730-744, 2000.

Crutzen, P. J.: Physical and chemical processes which control the production, destruction, and distribution of ozone and some other chemically active minor constituents, GARP Publications Series, 16, pp. 236-243, 1975.

Davis, J. M. and Speckman, P.: A model for predicting maximum and $8 \mathrm{~h}$ average ozone in Houston, Atmos. Environ., 33, 24872500, 1999.

Fast, D. J., de Foy, B., Caetano, E., Skamarock, W., Tie, X., Coulter, R., Barnard, J., and Wiedinmyer, C.: A meteorological overview of the MILAGRO field campaigns, Atmos. Chem. Phys, 7, 22332257, doi:10.5194/acp-7-2233-2007, 2007.

Grell, G. A., Peckham, S. E., Schmitz, R., McKeen, S. A., Wilczak, J., and Eder, B.: Fully coupled "online" chemistry within the WRF model, Atmos. Environ., 39, 6957-6975, 2005

Hoadley, J. L., Westrick, K., Ferguson, S. A., Goodrick, S. L., Bradshaw, L., and Werth, P.: The Effect of Model Resolution in Predicting Meteorological Parameters Used in Fire Danger Rating, J. Appl. Meteoro., 43, 1333-1347, 2004.

Kleinman, L. I., Daum, P. H., Imre, D. G., Lee, J. H., Lee, Y.-N., Nunnermacker, L. J., Springston, S. R., WeinsteinLloyd, J., and Newman, L.: Ozone production in the New York City urban plume, J. Geophys. Res., 105, 14495-14512, doi:10.1029/2000JD900011, 2000.

Lei, W., Zhang, R., Tie, X., and Hess, P.: Chemical characterization of ozone formation in the Houston-Galveston area, J. Geophys. Res., 109, D12301, doi:10.102/2003JD004219, 2004.

Lei, W., Zavala, M., de Foy, B., Volkamer, R., and Molina, L. T.: Characterizing ozone production and response under different meteorological conditions in Mexico City, Atmos. Chem. Phys., 8, 7571-7581, doi:10.5194/acp-8-7581-2008, 2008.

Li., G., Zhang, R., Fan, J., and Tie, X.: Impacts of biogenic emissions on photochemical ozone formation in Houston, Texas, J. Geophys. Res., 112, D10309, doi:10.1029/2006JD007924, 2007.

Lin, X., Trainer, M., and Liu, S. C.: On the nonlinearity of the tropospheric ozone production, J. Geophys. Res., 93(D12), 1587915888, doi:10.1029/88JD03750, 1988.

Mahmud, A., Tyree, M., Cayan, D., Motallebi, N., Kleeman, M., and Michael, J.: Statistical downscaling of climate change impacts on ozone concentrations in California, J. Geophys. Res. 113, D21103, doi:10.1029/2007JD009534, 2008.

Mass C. F., Ovens, D., Westrick, K. J., and Colle, B. A.: Does increasing horizontal resolution produce more skillful forecasts?, Bull. Am. Meteorol. Soc, 83, 407-430, 2002.

Misenis, C. and Zhang, Y.: An examination of sensitivity of WRF/Chem predictions to physical parameterizations, horizontal grid spacing, and nesting options, Atmos. Res., 97, 315-334, 2010 .
Misenis, C. and Zhang, Y.: An examination of sensitivity of WRF/Chem predictions to physical parameterizations, horizontal grid spacing, and nesting options, Atmos. Res., 97, 315-334, 2010.

Molina, L. and Molina, M. (Eds.), Air Quality in the Mexico MegaCity: An Integrated Assessment, Kluwer Academic Publishers, Dordrecht, The Netherlands, 150-180, 2002.

Noyes, P. D., McElwee, M. K., Miller, H. D., Clark, B. W., Van Tiem, L. A., Walcott, K. C., Erwin, K. N., and Levin, E. D.: The toxicology of climate change, Environ. Int., 35, 971-986, 2009.

Sillman, S.: The use of $\mathrm{NO}_{\mathrm{y}}, \mathrm{H}_{2} \mathrm{O}_{2}$, and $\mathrm{HNO}_{3}$ as indicators for ozone- $\mathrm{NO}_{\mathrm{X}}$-hydrocarbon sensitivity in urban locations, J. Geophys. Res., 100, 14175-14188, 1995.

Tie, X., Madronich, S., Li, G. H., Ying, Z. M., Zhang, R., Garcia, A., Lee-Taylor, J., and Liu, Y.: Characterizations of chemical oxidants in Mexico City: A regional chemical/dynamical model (WRF-Chem) study, Atmos. Environ., 41, 1989-2008, 2007.

Tie, X., Geng, F. H., Peng, L., Gao, W., and Zhao, C. S.: Measurement and modeling of $\mathrm{O}_{3}$ variability in Shanghai, China; Application of the WRF-Chem model, Atmos. Environ., 43, 42894302, 2009a.

Tie, X., Madronich, S., Li, G. H., Ying, Z. M., Weinheimer, A., Apel, E., and Campos, T.: Simulation of Mexico City Plumes during the MIRAGE-Mex Field Campaign Using the WRF-Chem Model, Atmos. Chem. Phys. 9, 4621-4638, doi:10.5194/acp-9-4621-2009, 2009b.

West, J. J., Zavala, M. A., Molina, L. T., Molina, M. J., Martini, F. S., McRae, G. J., Iglesias, G. S., and Colina, J. L.: Modeling ozone photochemistry and evaluation of hydrocarbon emissions in the Mexico City metropolitan area, J. Geophys. Res., 109, D19312, doi:10.1029/2003JD603652, 2004.

Ying, Z. M., X. Tie, and G. H. Li, Sensitivity of ozone concentrations to diurnal variations of surface emissions in Mexico City: A WRF/Chem modeling study, Atmos. Environ, 43, 851-859, 2009.

Zavala, M., Lei, W., Molina, M. J., and Molina, L. T.: Modeled and observed ozone sensitivity to 15 mobile-source emissions in Mexico City, Atmos. Chem. Phys., 9, 39-55, doi:10.5194/acp-939-2009, 2009a.

Zavala, M., Herndon, S. C., Wood, E. C., Onasch, T. B., Knighton, W. B., Marr, L. C., Kolb, C. E., and Molina, L. T.: Evaluation of mobile emissions contributions to Mexico City's emissions inventory using on-road and cross-road emission measurements and ambient data, Atmos. Chem. Phys., 9, 6305-6317, doi:10.5194/acp-8-6365-2009, 2009b.

Zhang, R., Lei, W., Tie, X., and Hess, P.: Industrial emissions cause extreme diurnal urban ozone variability, Proc. Natl. Acad. Sci. USA, 101, 6346-6350, 2004.

Zhang, Y., Dubey, M. K., Olsen, S. C., Zheng, J., and Zhang, R.: Comparisons of WRF/Chem simulations in Mexico City with ground-based RAMA measurements during the 2006-MILAGRO, Atmos. Chem. Phys., 9, 3777-3798, doi:10.5194/acp-9-3777-2009, 2009. 